\title{
Characterisation of Small Ruminant Production Systems in Semi-Arid Urban Areas of Northern Nigeria
}

\author{
${ }^{1}$ YUSUF, A; ${ }^{1 *}$ ARUWAYO, A; ${ }^{2}$ MUHAMMAD, IR \\ ${ }^{1}$ Department of Animal Science, Faculty of Agriculture and Agricultural Technology, Federal University Dutsin-ma, P.M.B 5001, Post \\ Code 821221, Dutsinma, Katsina State. \\ ${ }^{2}$ Department of Animal Science, Faculty of Agriculture, Bayero University, Post code 700231 Kano. \\ *Corresponding Author Email: aruwayoadebayo@gmail.com
}

\begin{abstract}
A survey to characterise small ruminant system in semi-urban areas of Northern Nigeria with Katsina state as a case study was carried out with use of structured questionnaires. A total of 147 livestock farmers were randomly chosen for the study. The data obtained was analysed by descriptive statistics. The study revealed that majority (51\%) of small ruminant keepers were within the age range of 18-30 years and most of them (71\%) were males. The results also revealed that majority $(71 \%)$ of the respondents had 1-10 years of experience in keeping sheep and goats, main source of foundation stock was through purchase (56\%) and majority $(60 \%)$ kept mixed herds of sheep and goats. The research also indicated that $44 \%$ of the farmers practise semi intensive system of management and that the respondents' mode of feeding the animals include grazing, grazing and browsing; and cut and carry. Grazing and browsing contributed $42 \%$ while purchase of feed accounted for $77 \%$. It was further revealed that the types of feeds consumed by the animals were forage legumes with concentrates $(53.4 \%)$ and forage grass with concentrates $(26.1 \%)$ which accounted for $79.5 \%$ of the total feed consumed. The farmers owned their stock mostly through purchase and were reared under semi-intensive system of management for meat and milk production. Most of the animals were fed through grazing and browsing along with supplementary feeds obtained through purchase. It was then concluded that ruminant production in the area of study has a lot of prospect in productivity and profitability.
\end{abstract}

\section{DOI: https://dx.doi.org/10.4314/jasem.v22i5.18}

Copyright: Copyright $\odot 2018$ Yusuf et al. This is an open access article distributed under the Creative Commons Attribution License (CCL), which permits unrestricted use, distribution, and reproduction in any medium, provided the original work is properly cited.

Dates: Received: 24 March 2018; Revised: 23 April: 2018; Accepted: 27 April 2018

Keywords: Semi-arid, urban areas, small ruminants, characterization

Ruminant production has been recognised for its contribution to livestock production in Nigeria. Ruminants form a significant proportion of the livestock production in Nigeria and possess obvious advantage over other livestock such as playing significant roles in the life of rural households (Aruwayo, et al., 2015). The importance of small ruminants in the tropics in general is well recognized (Williamson and Payne, 1978). Small ruminants are reared mainly for four functions, namely; meat, milk, skin and wool according to order of importance. Lebbie (2004) reported that sheep and goats play a significant role in the food chain and overall livelihoods of rural households, where they are largely the property of women and their children. They are veritable sources of income generation, household consumption, and hobby and as security against crop failure. Other advantages include lack of social and religious barrier to its production and consumption.

In Nigeria, Adu and Ngere (1979) described a compound system practiced by Hausas who are settled and therefore keep their small stock tethered in their compounds and feed them soilage in the rainy season. Otchere et al. (1985) reported that pastoralists Fulani in Giwa district of northern Nigeria allow sheep to accompany cattle for grazing but tethered their goats under shelter. Similar management have been reported by Wilson (1982), that the general consensus is that after crops have been harvested, small stock are let loose to feed on crop residues and fend for themselves. According to Ndamukong et al. (1989) a survey showed that in the North West province of Cameroun, $92 \%$ of the farmers' rear goats as against $21 \%$ who rear sheep. The most widely practice system of keeping sheep and goats was housing at night and tethering in the day time especially during cropping season. Most farmers gave their salt on a more or less regular basis (Ndamukong et al., 1989).

The distribution of ruminant livestock population by ecological zones of Nigeria as reported by FDLPCS (1992) shows that $71.50 \%$ sheep and $81.30 \%$ goats are found in the Savannah ecological zone. Winrock International (1992) reported an estimated population of sheep and goats in Africa as 127 million sheep and 
147 million goats. Lombin (2007) reported an estimated population of Nigerian goats as 40.8 million against 27 million sheep, 163 million cattle, 151 million poultry, 3.5 million pigs, 900,000 donkeys and 90,000 camels.

In subsistent production systems, in which the primary purpose is to meet family needs, many urban families indeed keep a few chickens, two to three sheep and goats for occasional consumption. The animals scavenge for a large part of their required feed, but are supplemented with household food processing wastes and therefore performance is poor and mortality rate is high (Maxwell, 1994). In urban livestock production, the system is mostly semi-intensive, where little feed is given to the animals as a supplement and later allowed to go out to search for basal feeds. This study was therefore conducted to characterise ruminant farmers in Katsina metropolis and ascertain the ruminant production systems adopted by them.

\section{MATERIALS AND METHODS}

Description of the Study Site: The study was carried out in Katsina Local Government Area of Katsina State which lies between $12^{\circ} 15 \mathrm{~N} "$ and $7^{\circ} 3 \mathrm{E} "$ in the Sudan Savanna Zone of Nigeria (Nkromah, 2007). It covers an estimated land area of 49,895 square kilometres. The population of the State is 5.8 million during the 2006 National Head Count (NPC, 2006). Katsina State has hot and dry climatic conditions for most of the year. The hottest months are March to May with temperature ranging from $23^{\circ} \mathrm{C}$ to $42^{\circ} \mathrm{C}$. The annual rainfall varies from $700 \mathrm{~mm}-1000 \mathrm{~mm}$ and rainy season is usually from June to September. The people of Katsina State are mainly farmers, petty traders and civil servants (Katsina State Diary, 2002).

Data Collection and Statistical Analysis: The survey was conducted using structured questionnaires that were designed and administered to one hundred and fifty (150) ruminant farmers in Katsina metropolis, using a stratified random sampling technique. Data was collected on biodata of the farmers, animal kept and number, duration of involvement in ruminant farming and purpose, system of management, flock composition and feeding regime of the animals. Data obtained from the structured questionnaires were analysed for descriptive statistics in all the parameters using Statistical Package for Social Sciences (SPSS).

\section{RESULTS AND DISCUSSION}

Biodata of respondents Respondents: Table 1 presents biodata of respondents keeping sheep and goats in Katsina Metropolis as of 2011. The data obtained revealed that majority $(51 \%)$ of small ruminant keepers were within the age range of $18-30$ years. The other categories were 31-43 years that accounted for (31\%) while from 57-81 years the percentage was 21 . Majority of the respondents were males (71\%) and others were females. It was also discovered that most of the respondents $(69 \%)$ were married, $22 \%$ were single while others were widows $(6 \%)$ and divorced $(39 \%)$. The respondents had primary school education and tertiary level education $36 \%$ each, followed by those with secondary school education who had $28 \%$.

Majority of sheep and goats keepers in the study area were within the age range of $18-30 \%$ with average age of 24 years in sample population. This indicated that majority of sheep and goat keepers were within their active age with strength and potential for improved production practices. Ajala et al. (2008) reported that active age range of stock owners is expected to make them more receptive to innovations.

Sheep and goat keeping in the study area is a male dominated activity and majority are married. This was supported by Aruwayo et al. (2015) that ruminant production is male dominated in Katsina state. This could be attributed to the fact that keeping sheep and goat requires men who are energetic youth that can endure the stress and capital requirements of ruminant production. The study also revealed that $71 \%$ of the owners from the study area had 1-10 years of experience in keeping sheep and goats which could be an advantage in terms of vigour for the work and ability to imbibe new farming techniques.

It could be deduced from the study that $36 \%$ had tertiary level of education while $28 \%$ had secondary level of education. It therefore implies that the sheep and goat keepers were formally educated. Education is necessary tool for knowing proper ways of keeping livestock.

Aruwayo et al. (2015) reported that farmers' low level of education will make farmers find it difficult to adopt modern methods of ruminant production. It can then be deduced from the study that farmers will have access to latest information on improved livestock production.

It was observed that majority $(62 \%)$ of the sheep and goats keepers in the area were married males and female which can be an advantage in stabilizing the production through the use of family labour and ability to harness family labour. The dominance of married male may foster more careful and more accurate 
system of keeping the animals and capital mobilisation for improved ruminant production.

Table 1: Biodata of respondents keeping sheep and goats in

\begin{tabular}{lll}
\multicolumn{2}{c}{ Katsina Metropolis } \\
\hline Variables & Frequency & Percentage (\%) \\
\hline Age range & & \\
(Yrs) & & \\
$18-30$ & 75 & 51 \\
$31-43$ & 45 & 31 \\
$44-56$ & 21 & 14 \\
$57-69$ & 3 & 2 \\
$70-81$ & 3 & 2 \\
Total & 147 & 100 \\
Sex & & \\
Male & 104 & 71 \\
& & \\
Females & 43 & 29 \\
Total & 147 & 100 \\
Marital & & \\
Status & & \\
Married & 102 & 69 \\
Single & 32 & 22 \\
Widow & 9 & 6 \\
Divorced & 4 & 3 \\
Total & 147 & 100 \\
Level of & & \\
education & & 36 \\
Primary & 53 & 28 \\
Secondary & 42 & 36 \\
Tertiary & 52 & 100 \\
Total & 147 & Source: Field survey. \\
\hline \multicolumn{2}{l}{} &
\end{tabular}

Reasons for keeping Sheep and Goat: Reasons for keeping small ruminants is presented in table 2 . They are for milk, meat, prestige and for commercial purposes. Majority (58\%) kept it for commercial purpose, followed by those who kept it for meat and milk (21\%) while the remaining $14 \%$ kept it as prestige. The result showed that $58 \%$ of the livestock farmers kept the animals for commercial purpose, $21.1 \%$ keep for meat and milk. The study is therefore inconsistent with report of Williamson and Payne (1978) that small ruminants are reared mainly for four functions; namely: meat, milk, skin and wool according to order of importance.

Table 2: Reasons for sheep and goat

\begin{tabular}{lcl}
\hline Variables & Frequency & Percentage (\%) \\
\hline Milk production & 2 & 1.3 \\
Meat & 8 & 5.4 \\
Prestige & 21 & 14.2 \\
Meat and milk & 31 & 21.1 \\
Commercial & 85 & 58 \\
Total & 147 & 100 \\
\hline \multicolumn{3}{c}{ Source: Field survey. }
\end{tabular}

Respondents experience in keeping sheep and goats: Table 3 indicates the respondents experience in keeping sheep and goats in Katsina metropolis. The data obtained revealed that small ruminants' keepers in the area had 1-40 years of experience in keeping sheep and goats. Majority $(71 \%)$ of the respondents had 1-10 years of experience while the least $(0.7 \%)$ had 26-30 years of experience.

Table 3: Respondents experience in keeping sheep and goats in Katsina metropolis

\begin{tabular}{|c|c|c|}
\hline Variables & Frequency & Percentage $(\%)$ \\
\hline \multicolumn{3}{|l|}{ Years of Experience } \\
\hline $\begin{array}{l}\text { in Keeping Sheep } \\
\text { and Goats }\end{array}$ & & \\
\hline $1-10$ & 105 & 71.42 \\
\hline $11-15$ & 19 & 12.93 \\
\hline $16-20$ & 11 & 7.50 \\
\hline $21-25$ & 4 & 2.72 \\
\hline $26-30$ & 1 & 0.70 \\
\hline $31-40$ & 5 & 3.70 \\
\hline Total & 147 & 100 \\
\hline
\end{tabular}

Table 4: Stock owned by the respondents

\begin{tabular}{|c|c|c|}
\hline Variables & Frequency & Percentage $(\%)$ \\
\hline \multicolumn{3}{|l|}{ Years of Experience in } \\
\hline \multicolumn{3}{|l|}{ Keeping Sheep and Goats } \\
\hline $1-10$ & 105 & 71.42 \\
\hline $11-15$ & 19 & 12.93 \\
\hline $16-20$ & 11 & 7.50 \\
\hline $21-25$ & 4 & 2.72 \\
\hline $26-30$ & 1 & 0.70 \\
\hline $31-40$ & 5 & 3.70 \\
\hline Total & 147 & 100 \\
\hline Variable & Frequency & Percentage $(\%)$ \\
\hline Purchase & 82 & 56 \\
\hline Inheritance & 41 & 28 \\
\hline Gift & 19 & 13 \\
\hline Dowry & 5 & 3 \\
\hline Total & 147 & 100 \\
\hline \multicolumn{3}{|l|}{$\begin{array}{l}\text { No. of animals possessed } \\
\text { by the keepers }\end{array}$} \\
\hline $1-10$ & 81 & 55.10 \\
\hline $11-15$ & 25 & 17.0 \\
\hline $16-20$ & 19 & 12.92 \\
\hline $21-25$ & 9 & 6.12 \\
\hline $26-30$ & 6 & 4.08 \\
\hline $31-35$ & 1 & 0.70 \\
\hline Total & 147 & 100 \\
\hline Flock Composition of & & \\
\hline \multicolumn{3}{|l|}{ Sheep and Goat Kept } \\
\hline Sheep and Goats & 88 & 60 \\
\hline Sheep only & 37 & 25 \\
\hline Goats only & 19 & 13 \\
\hline Ram only & 3 & 2 \\
\hline Total & 147 & 100 \\
\hline
\end{tabular}

Respondent's stock: Table 4 showed the stock owned by the farmers. The sources of foundation stock were purchase, inheritance, gift and dowry. But purchase $56 \%$ and inheritance $28 \%$ accounted for $84 \%$. It was also discovered that the respondents had 1-35 animals, but majority (55\%) had 1-10, followed by 11-15 (17\%) others were lowest with $(0.7 \%)$. The table also indicated that the composition of the animal flock was either sheep, goat, ram or the combination. Majority 
$(60 \%)$ of the respondents kept sheep and goat, while $25 \%$ kept sheep only and $13 \%$ kept goat only. The sources of sheep and goats indicated that majority $(56 \%)$ of the farmers purchase their stock. This is contrary to Alexander (1988) who reported that livestock production in the rural areas of northern Nigeria are normally characterized by inheritance as a form of ownership which gives them opportunity. The flock composition of the study area revealed that majority $(25 \%)$ of the farmers rear sheep only as against (13\%) of the farmers who rear goats only. This is in contrast with a survey in the West province of Cameroun where $92 \%$ of the farmers rear goats as against 21\% who rear sheep (Ndamukong et al., 1998).

Table 5: Respondents sources and method of obtaining Feed

\begin{tabular}{|c|c|c|}
\hline Variables & Frequency & $\begin{array}{l}\text { Percentage } \\
(\%)\end{array}$ \\
\hline \multicolumn{3}{|c|}{ Methods of feeding animals } \\
\hline Grazing & 16 & 11 \\
\hline Grasses and browses & 62 & 42 \\
\hline Cut and carry & 39 & 27 \\
\hline Any other & 30 & 20 \\
\hline Total & 147 & 100 \\
\hline \multicolumn{3}{|l|}{$\begin{array}{l}\text { Means of obtaining } \\
\text { supplementary feeds } \\
\text { Purchase }\end{array}$} \\
\hline Yes & 113 & 77 \\
\hline No & 34 & 23 \\
\hline Total & 147 & 100 \\
\hline
\end{tabular}

Respondent's sources of Feeding Sheep and Goats: Table 5 shows the respondents sources of feed for sheep and goats in Katsina metropolis. The sources of feeding sheep and goat in Katsina metropolis include; grazing, grazing and browses, cut and carry and any other source. Grazing and browses contributed $42 \%$ while purchase of feed accounted for $77 \%$. Majority $(42 \%)$ of the respondents interviewed indicated that their source of feed is grass and browses. This is in agreement with the report of Wilson (1982) who reported that the consensus is that after crops have been harvested, small stocks are let loose to feed on crop residues

Table 6: Type of feeds offered

\begin{tabular}{lll}
\hline Variables & Frequency & Percentage (\%) \\
\hline $\begin{array}{l}\text { Types of feed offered } \\
\text { Forage legumes with }\end{array}$ & 56 & 53.4 \\
concentrates & & \\
Concentrates only & 30 & 26.1 \\
Forage grasses only & 13 & 11 \\
Forage grass with concentrate & 5 & 4.3 \\
Total & 104 & 94.8 \\
\hline Source: Field Survey. & &
\end{tabular}

Type of Feeds Offered: Table 6 shows the type of feeds used for feeding sheep and goat within Katsina metropolis. The types of feed consumed by sheep and goat in Katsina metropolis were forage legumes with concentrates, forage grass with concentrates, concentrate only and forage grasses. However, forage legume with concentrate $53.4 \%$ and concentrate only $26.1 \%$ accounted for $79 \%$ of the total feed.

Systems of Management and Type of Mineral Supplement Offered to the Animals: System of management and type of mineral supplements offered to the animals by respondents in Katsina metropolis are shown in Table 7 . It reveals that the systems of management of sheep and goat practiced by the respondents were intensive system, semi-intensive and extensive systems. Majority (44\%) engaged in semiintensive, (38\%) engaged in an intensive, others engaged in an extensive system. It was also observed that type of mineral supplements offered respondents were table salt and multinutrient block. But table salt (23\%) and multinutrient (35\%) accounted for 58\% against others with $42 \%$ that do not give any of them. The study indicated that most of the respondents (44\%) engaged in the semi intensive system followed by $38 \%$ that engaged in the intensive system while only $18 \%$ engaged in an extensive system. This indicated that small ruminant production in this area has improved and could be more profitable.

Table 7: Systems of management and type of mineral supplement offered to the animals

\begin{tabular}{lll}
\hline Variables & Frequency & Percentage \\
\hline System of management & & \\
Intensive & 56 & 38 \\
Semi-intensive & 65 & 44 \\
Extensive & 26 & 18 \\
Total & 147 & 100 \\
Mineral supplements & & \\
Table salt & 34 & 23 \\
Multinutrient block & 51 & 35 \\
None of the above & 62 & 42 \\
Total & 147 & 100 \\
\hline \multicolumn{2}{c}{ Source: Field Survey. }
\end{tabular}

The findings of this study contradicted that of Von Kaufman (1989) who reported that in densely populated areas, small ruminants are tethered or confined to protect crops and are therefore hand-fed albeit with the same feed resources as in free roaming system and that of Ajala and Gefu (2003) who also reported that small ruminants are mostly managed under extensive systems in Northern Nigeria. Greater percentage of the respondents interviewed (42\%) said that they neither give multinutrient block nor table salt, probably due to economic down town in the country. This is not in conformity with the report of Ndamukong et al. (1989) that most farmers gave their animals salt on a more or less regular basis. This might 
impede the productivity of the animals since the minerals are needed for their overall welfare.

Conclusion: From this study, it was concluded that farmers rear sheep and goats which are mostly owned through purchase under semi-intensive system of management for meat and milk production. Most of the farmers feed their animals through grazing and browsing, and purchase supplementary feed for the animals. The productivity of the ruminants in the area of study could be improved through better management practices like giving of multinutrients block to them.

\section{REFERENCES}

Adu, IF; Ngere, LO (1979). The Indigenous Sheep of Nigeria. World Review Animal J. 15:51-62

Ajala, MK., Lamidi OS; Otaru, SM (2008). Peri-Urban Small Ruminant Production in Northern Guinea Savanna. Nigeria. Asian J. of Anim. and Vet. Adv. 3(3); 138-146, 2008.

Ajala, MK; Gefu, JO (2003). Socio-economic factors influencing small ruminant management practices in Kaduna State. Moor J. Agric. Res. 4:274-280.

Alexander, NO (1988). Behaviour and Adaptation of Pseudo-Ruminants in the Tropics. Australian Centre of Agricultural Research.

Aruwayo, A; Tiri, GD; Yahaya, MA; Akinyemi, M (2015). An Emperical Analysis of Ruminant Production In Dutsinma Local Government Area, Katsina State, Nig Int J. Inov Agric \& Bio. Res. 3(2):34-40.

FDLCPS (1992). Federal Department of Livestock and Pest Control Services. Nigerian Livesock Resources, 2, National Synthesis Report by Resources Inventory and Management Limited, to FDLPCS, Abuja, Nigeria. 40pp.

Garba, H. S., Dangi, A. I.and Bako, A. (1994). A Survival of Small Ruminants on Refuse Dumps in Sokoto Metropolis. 19th Animal Conference of the Nigerian Society of Animal Production.

Katsina State Diary (2002). A publication of the Ministry of Information and Home Affairs.

Lakpini, CAM (2002). Feed and Feeding Strategies for Small Ruminants in various Physiological States. In Lakpini, C.A.M., Echoche, O.W and Gefu, J.O. (eds) Small Ruminant Production Training Workshop. National Animal Production Research Institute, Ahmadu Bello University, Zaria.
Lebbie, SHB. (2004). Goats under Household Conditions. Small Rum. Res, 51: 131 - 136

Lombin, L (2007). Analyzing News about African Agriculture. Reviewed on 02-10-2010.

Maxwell, DG (1994). The Household Logic of Urban Farming in Kampala. In Cities Feeding People; an examination of Urban Agriculture in East Africa. International Development Research Centre Ottawa, Canada. Pp. 146.

Ndamukong, KJ; Sewell, MM; Asangi, MF (1989). Management and Productivity of Small Ruminants in the West Province of Cameroun. Institute of Animal Research, Mankon Station, Cameroun. www.ncbinlm.nih.gov/pubmed/2749905.

Nkromah, G (2007). Nigeria Fastened with Nails" Al-Ahram weekly. Retrieved on 24-042007.

NPC (2006). National Population Commission, Nigeria. Nigeria Demographic and Health Survey 2006. Calverton Maryland: National Population Commission and ORC Macro.

Otchere, EO.; Ahmed, HU; Adesipe, YM; Kallah, MS; Muhammed, N (1985).Livestock Production Among Pastoralists in Giwa District, Kaduna State, Nigeria.Unpublished Mimeo. Livestock System Research Project, NAPRI, Shika, Zaria.

Von Kaufman, R; Francis; P (1989). The Elements of Effective Extension Service to sheep goat production in the Humid Tropics of West Africa In: Timon, V.M. and Baker, R.P (Eds). Sheep and goat Meat Production in the tropics of West Africa. F.A.O Animal Production and Health Paper 70. F.A.O (Food and Agricultural Organisation of the United Nations), Rome, Italy. Pp. 128-141. www.fao.org./Wairdocs/ILRI/X5519blf.htm.

Williamson, G; Payne, WJA (1978). An Introduction to Animal Husbandry in the Tropics ( $3^{\text {rd }}$ Ed) Longman, London.

Wilson, RT (1982). Small Ruminant Breed Productivity in Africa (ed.).R. M. Gatemby and JC. M Trail ILCA, Addis Ababa, Ethiopia. Wild Animal Rev. 53:8 - 14.

Winrock International (1992). Assessment of Animal Agriculture in Sub-Saharan Africa. Winrock International Institute for Agricultural Development Morrilton, Arkansas, U. S. A. pp. 125. 